ELORE (ISSN 1456-3010), vol. 20 - 1/2013.

Julkaisija: Suomen Kansantietouden Tutkijain Seura ry.

[http://www.elore.fi/arkisto/1_13/granbom-herranen.pdf]

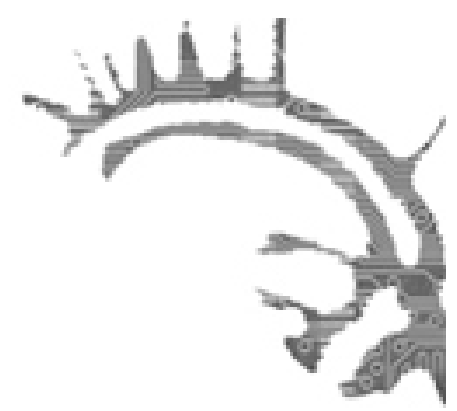

\title{
KIRJA-ARVIO
}

\section{VITSIEN TUTKIMUS EI OLE VITSIKÄSTÄ}

\author{
LAINESTE, LIISI \& BRZOZOWSKA, DOROTA \& CHŁOPICKI, WŁADYSŁAW \\ (TOIM.) 2012: Estonia and Poland: Creativity and tradition in cultural communication. \\ Volume 1: Jokes and their relations. Tartu: ELM Scholarly Press. <http://www.folklore. \\ ee/pubte/eraamat/eestipoola/>. 284 sivua.
}

\section{Liisa Granbom-Herranen}

Estonia and Poland: Creativity and tradition in cultural communication on esimerkki siitä, mitä kansainvälisellä yhteistyöllä voidaan saavuttaa. Teos on tulosta kolme vuotta kestäneestä Viron ja Puolan huumorin monien osa-alueiden tutkijoiden yhteistyöstä. Tätä työtä ovat tukeneet sekä Viron että Puolan tiedeakatemiat. Kyse ei kuitenkaan ole vain yhdestä projektista ja sen tuloksena julkaistusta teoksesta, sillä esimerkiksi verbaalisen huumorin ja aggressiivisuuden yhteyttä käsittelevän tutkimuksen materiaali on koottu internetistä Viron oikeusministeriön projektin yhteydessä. Huumori on vakava asia. Sitä voidaan käyttää poliittisiin tarkoituksiin, yhteiskunnan epäkohtien käsittelyyn tai nimettömään ilkeilyyn. Tämä kaksiosaiseksi suunnitellun teoksen ensimmäinen, viime vuonna ilmestynyt osa keskittyy vitseihin sekä huumoriin liittyviin ilmiöihin. Teoksen toinen osa keskittyy identiteettiin.

Kuten kirjan toimittajat esipuheessaan toteavat, eroavat virolainen ja puolalainen kulttuuri toisistaan, vaikka kummankin maan historiassa on nähtävissä samankaltainen saksalainen, venäläinen ja neuvostoaikainen vaikutus. Viron ja Puolan välisestä maantieteellisestä välimatkasta huolimatta historiassa on monia yhtymäkohtia usean sadan 
vuoden ajalta ennen kaikkea kansan ja vallanpitäjien suhdetta tarkasteltaessa. Teoksen aiheen kannalta keskeistä on yhteinen sosialistinen historia Neuvostoliiton hallinnon ajalta, joka päättyi 1989 niin sanottuun kansojen kevääseen.

\section{YHTEISTYÖN TULOS}

Yhteisprojektin tavoitteena on ollut selvittää itäeurooppalaisen, ensisijaisesti sosialistisen ja sosialisminjälkeisen ajan huumoria, sen tuotoksia ja prosesseja. Aikakaudet on julkaisussa pääsääntöisesti jaettu Arvo Krikmannin teoksen ensimmäisessä artikkelissa esittämiin kolmeen kauteen: neuvostoaika, 1990-luku ja nykyisyys. Tosin joissakin artikkeleissa, kuten stand-up-komiikkaa ja sen taustoja käsittelevissä Liisi Lainesten ja Władysław Chłopickin artikkeleissa, tarkastellaan huomattavasti varhaisempia aikoja. Teos rakentuukin varsin selkeästi kronologian kautta. Teoksen alkuosa keskittyy perinteisiin huumorin lajeihin, erityisesti vitseihin. Näistä siirrytään artikkeleihin, joissa etsitään huumorin lajityypillisiä reuna-alueita. Uusinta aikaa - internetiä ja kaupunkiympäristöä - käsittelevät artikkelit sijoittuvat teoksen loppuosaan.

Tämä jako on lukijan kannalta toimiva. Ainoa artikkelipari, jonka asettelua mietin, käsitteli sensuuria ja huumorin käytön tarjoamia mahdollisuuksia sen kiertämisessä. Yhtäältä nykyinen sijainti perinteisen huumorin ilmentymien ja uusien kontekstien luomien huumorin lajien välillä on kronologisesti perustelua. Toisaalta tuo artikkelipari olisi voinut lisätä luetun ymmärtämistä, mutta tavallaan oli mainiota tässä kohdassa oivaltaa jotakin. Itselleni kävi näin tutustuessani estraditaiteen ja stand-up-komiikan yhteyksiin. Mieleen tuli, että Suomessa aikaperspektiivi on toinen kuin keskieurooppalaisissa kulttuureissa. Meillä hovinarrit ja koomikot eivät ole samalla tavalla olleet näkyvässä roolissa kuin Puolassa, jossa sekä taloudellista että yhteiskunnallista valtaa käyttänyt eliitti on ollut varsin kiinteässä yhteydessä niin Keski- kuin Etelä-Euroopankin huumoria hyödyntäviin kulttuurisiin virtauksiin. Ooppera ja teatteri käyttävät edelleen komiikkaa ja huumoria varsin vakavien asioiden esittämisessä. Italialaisen Giuseppe Verdin luoma hahmo Rigoletto toimii edelleen sekä perinteisissä aateliselämään että modernisoidussa kasinoon sijoittuvassa lavastuksessa kuin sosialismin ajan koomikko, joka kokeilee yleisönsä sietokykyä.

Maissa, joissa neuvostoaikaa (Soviet time) ja postsosialismia (post-sosialistic) ei koettu itse, ei vuoden 1989 kansojen kevät (spring of nations of 1989) voi merkitä samaa kuin entisen Neuvostoliiton alueilla ja liittolaisille. Suomen kielessä ei ole varsinaisesti vastineita ilmiöille socialist jokelore ja post-socialist jokelore, vaikka oli meilläkin erityisesti tähän aikakauteen liittyneitä vitsejä radio Jerevanista tankeroihin. Erona on se, että suomalaisten vitsien kärki ei ollut suunnattu samalla lailla vallanpitäjiin kuin sosialistisessa ja sosialisminjälkeisessä huumorissa. Artikkeleja lukiessa kohtaa väistämättä jonkinlaisen ulkopuolisuuden tai osattomuuden näihin näkökulmiin. Huumorin historia liittyy kansakunnan historiaan ja on osa politiikan sekä vallankäytön historiaa. 


\section{AIHE YHDISTÄ̈̈ ARTIKKELIPAREJA}

Kuten mainittu, teos koostuu kahdeksasta virolaisen ja kahdeksasta puolalaisen tutkijan artikkelista, jotka ovat luettavissa pareina. Erityisaihe (huumori) ja siihen liittyvät pariartikkelit varsin eriytyneistä aiheista pienillä kielialueilla johtavat siihen, että yhdeltä tutkijalta on julkaistu useampia artikkeleita. Tietysti voisi ajatella, että näissä tapauksissa koostettu monografia olisi tehokkaampi, mutta mielestäni juuri vertailuaspekti on oleellinen osa julkaisun kiinnostavuutta ajatellen.

Artikkelit ansaitsisivat pääsääntöisesti tulla läpikäydyksi jokainen vuorollaan. Koska siihen ei ole mahdollisuutta, mainitsen vain artikkeliparien käsittelemät aiheet. Teoksen aloittavat vitsit koskien kolmea osallista (kansaa, ammattia tms.) (Arvo Krikmann ja Dorota Brzozowska) ja toisena ovat naista ja perhettä käsittelevät vitsit (Liisi Laineste ja Dorota Brzozowska). Seuraavat kolme artikkeliparia muodostavat toisenlaisen kokonaisuuden: stand-up-komiikka (Liisi Laineste ja Władysław Chłopicki); poliittinen huumori (Martin Rebane ja Marcin Poprawa); sensuuri (Maarja Lõhmus ja Gaweł Strządała). Viimeiset artikkelit liittyvät uusiin medioihin, urbaanistumiseen sekä huumorin negatiivisiin puoliin: visuaalinen internethuumori (Anneli Baran ja Tomasz Piekot); aggressiivisuuden ja huumorin suhde (Liisi Laineste ja Anna Tereszkiewicz) sekä seinäkirjoitukset (Piret Voolaid ja Grzegorz Szpila).

Kukin artikkeli on sekä itsenäinen tieteellinen artikkeli, pari toiselle samaa aihetta käsittelevälle että osa laajempaa Viro-Puola-yhteisprojektia. Koen artikkeliparien kohdentavan myös lukijan huomiota niissä käsiteltyyn ilmiöön, mutta olevan oman tiedekulttuurinsa tulosta ja ennen kaikkea yksilöllisiä tuotoksia. Kokoelma sisältääkin keskenään hyvin erilaisia ja eritasoisia, mutta ennen kaikkea teoreettisesti painottuneita tekstejä. Tutkimusaineistot vaihtelevat niin laadultaan kuin määrältään, laajimmillaan tarkastelu sisältää yli 20000 vitsiä ja pienimmillään 20 internetistä haettua lausetta tai viisi haastattelua. Aineistot sijoittuvat eri aikakausiin: varhaisimmat ovat neuvostoajalta ja uusimmat vuoden 2012 kesäkuulta.

Yksi teoksen ja artikkelien ansioista on tutkimusaineistojen esittely. Erityisesti virolaiset tutkijat tuntuvat tutkimuksissaan tukeutuvan laajoihin aineistoihin. Monissa artikkeleissa on myös kiinnitetty huomiota tutkimusaineiston viittauksiin. Pienenä yhdistävänä lisänä voisi tällaisessa runsaasti aineistoa esittelevässä artikkelikokoelmassa kiinnittää huomiota aineistoviittausten samankaltaisuuteen. Se olisi avuksi lukijalle. Teos on niin selkeästi tieteellinen julkaisu, että sitä lukevat ensisijaisesti opiskelijat ja tutkijat, ja tämä yleisö on uteliasta: lähteitä tarkastellaan. Erityisesti internetissä sijaitsevat aineistot (esimerkiksi Eesti Kirjandusmuuseumin tietokannat, http://www.folklore.ee/ ebaas/ [14.2.2013]) herättänevät mielenkiintoa.

Ei-huumorintutkijan näkökulmasta ovat tutkimusmenetelmät mielenkiintoisia, nehän eivät ole mitenkään erityisesti huumoriin sidottuja. Varsin monet kirjoittajat esittelevät tutkimuksensa vaiheita ja käyttämiänsä tutkimusmenetelmiä jopa niin, että jotkut artikkeleista toimivat oppikirjamaisesti. Tällä tarkoitan nimenomaan tekstin selkeyttä ja menetelmän yhdistämistä käytäntöön, mikä ei varsinaisesti kevennä tekstin luettavuutta, mutta lisää kiinnostavuutta. 


\section{LOPPU HYVIN...}

Monien artikkelien kirjoittajat ovat kansainvälisesti tunnettuja huumorin tutkijoita. Tutkijat edustavat myös useita tieteenaloja, joista jotkut ilmenevät tekstistä. Kuitenkin huumorin tutkijoita laajemmalle lukijakunnalle olisin kaivannut teoksen loppuun joitakin perustietoja kirjoittajista. Me suomalaiset tunnistamme lähinnä joitakin virolaisia kirjoittajia.

Esimerkkien alkukielisyys on sekä positiivinen lisä artikkeliin että harmillinen monimutkaistaja lukijalle. Huumoriaineistojen (kuten kaikkien merkityksiä sisältävien aineistojen) esittely on aina haaste vieraskieliselle esitykselle. Käytettäessä esimerkkejä on vitsi esitettävä ensin alkukielellä ja sitten käännöksenä. Tämän jälkeen täytyy erityisilmaukset selittää ja lopuksi tulee kuvata, mitä vitsillä oikeastaan tarkoitetaan. Tämä koskee myös kuvia käyttäviä huumorin lajeja, joiden värit tulevat teoksen internetjulkaisussa, toisin kuin mustavalkoisessa niteessä, esiin. Kuvaamis- ja selittämisprosessissa huumorista katoaa sen satuttavuus. Tosin tässä on kyseessä tieteellinen artikkeli, joten vitsit siis eivät ole hauskoja tai tylsiä, vaan aineistoa.

Ideana tällainen yhteen aiheeseen kohdistettujen artikkelien parittainen esitteleminen on lukijalle mielenkiintoinen ja avaa uusia ajatuksia. Aihekohtaiset tieteelliset artikkelijulkaisut ovat tuttuja, mutta tällainen selkeä rinnakkain asettelu on uutta ja sopisi varmasti usean oppiaineen tai aihepiirin käyttöön. Tässä teoksessa artikkeliparit toimivat hyvin kokonaisuutena. Niissä on varsin vähän toistoa tai päällekkäisyyttä huolimatta siitä, että ne käsittelevät samaa ilmiötä.

Estonia and Poland: Creativity and tradition in cultural communication on monipuolinen artikkelikokoelma ja kokonaiskatsaus huumoriin ja sen ilmentymiin neuvostoaikaisessa sosialistisessa yhteiskunnassa sekä sosialisminjälkeisessä kulttuurissa. Osa viimeksi mainitusta ei varsinaisesti eroa muusta eurooppalaisesta kulttuurista, mutta eräänlainen hiljainen tieto ja yhteiskunnallinen nauru tuntuvat värittävän vielä tätä päivää, jolloin kansojen keväästä on kulunut yli kaksikymmentä vuotta. Jään mielenkiinnolla odottamaan teoksen toisen osan ilmestymistä.

Kasvatustieteen tohtori, filosofian maisteri Liisa Granbom-Herranen toimii akatemian tutkijatohtorina Jyväskylän yliopistossa. 